\title{
STRATEGIC POLICY INTELLIGENCE TOOLS W KONTEKŚCIE REGIONALNEGO ZARZAZDZANIA ROZWOJEM PRZESTRZENNYM
}

\section{Abstract \\ Strategic Policy Intelligence Tools in the Context of Regional Management of Spatial Development}

This article aims to analyse and evaluate the implementation of the strategic policy intelligent tools to determine the vision of the spatial development of the territory. Based on a review of sixteen regional spatial development plans proposed strategic policy intelligent tools at various stages of adoption planning studies.

Keywords: Strategic Policy Intelligence Tools, spatial management, regional spatial development plan

\section{Streszczenie}

Celem artykułu jest analiza i ocena możliwości implementacji Strategic Policy Intelligence Tools do określania wizji rozwoju przestrzennego danego regionu. Na podstawie przeglądu planów zagospodarowania przestrzennego województwa, zaproponowano wykorzystanie Strategic Policy Intelligence Tools na poszczególnych etapach uchwalania opracowań planistycznych.

Słowa kluczowe: Strategic Policy Intelligence Tools, zarządzanie rozwojem przestrzennym, plan zagospodarowania przestrzennego województwa

\section{Wprowadzenie}

Samorząd terytorialny, działając w dynamicznie zmieniającym się otoczeniu, potrzebuje skutecznych metod do określania przyszłości danego terytorium w długoletniej perspektywie. Coraz większe znaczenie zyskują w Polsce 
Strategic Policy Intelligence Tools, które rzadko bywają implementowane przez władzę publiczną. Celem artykułu jest rozpoznanie możliwości aplikacji Strategic Policy Intelligence Tools w rozwoju przestrzennym danego terytorium. W części teoretycznej podjęto próbę uporządkowania stanu wiedzy pojęciowo-koncepcyjnej dotyczącej Strategic Policy Intelligence Tools, natomiast w empirycznej przeanalizowano i oceniono aktywność podmiotów samorządów regionalnych na rzecz kształtowania zmian w przestrzeni. W publikacji korzystano z literatury przedmiotu, raportów instytucji naukowych, międzynarodowych opracowań i dokumentów krajowych oraz danych statystycznych Banku Danych Lokalnych GUS. W części praktycznej analizie poddano plany zagospodarowania przestrzennego województwa odnalezione na stronach internetowych Urzędów Marszałkowskich, w Biuletynie Informacji Publicznej i w Wojewódzkim Dzienniku Urzędowym. Przyjętą w opracowaniu metodą badawczą jest kwerenda publikacji wsparta krytyczną analizą piśmiennictwa oraz analizą i konstrukcją logiczną. Zakres przeprowadzonych badań obejmował następujące etapy:

I. Identyfikacja i klasyfikacja Strategic Policy Intelligence Tools.

II. Określenie etapów uchwalania opracowań planistycznych na podstawie przeglądu planów zagospodarowania przestrzennego województwa.

III. Propozycja wykorzystania Strategic Policy Intelligence Tools na poszczególnych etapach uchwalania opracowań planistycznych.

\section{Istota Strategic Policy Intelligence Tools}

Strategic Policy Intelligence Tools definiowane są jako zbiór działań służących decydentom wyszukiwaniu i rozpowszechnianiu informacji w celu podjęcia bezstronnej, właściwej i perspektywicznej decyzji [Clar i in., 2008c: 3]. Obejmują one metody i techniki zarządzania strategicznego. Strategic Policy Intelligence Tools dotychczas były stosowane i rozwijane od lat pięćdziesiątych XX wieku w japońskim i amerykańskim, a później europejskim biznesie. Jak spostrzegł Jan Skonieczny, od połowy lat dziewięćdziesiątych zeszłego wieku zostały one zaadaptowane na potrzeby zarządzania terytorialnego, a w szczególności regionalnego [Skonieczny, 2006: 5]. W literaturze anglojęzycznej Strategic Policy Intelligence Tools oznaczane są w skrócie SPI [Tübke i in., 2001: 10; Clar i in., 2008b: 20]. W literaturze krajowej brak powszechnie przyjętego polskojęzycznego odpowiednika nazwy tej metodyki, występuje luka terminologiczna w tym zakresie. Autorka pragnie zauważyć, iż nie jest to łatwe tłumaczenie językowe. Wśród badaczy nie ma konsensusu. Na określenie tego pojęcia proponuje termin informacyjno-wywiadowcze narzędzia strategiczne. W pracy jednak pragnie pozostać przy anglojęzycznej nazwie.

Zdaniem autorki Strategic Policy Intelligence Tools należy wykorzystywać w celu przewidywania przyszłości rozwoju danego terytorium poprzez szczegółowe 
skanowanie obecnego stanu i ocenę, a także identyfikację strategicznych czynników, obszarów wpływających na rozwój danego terytorium. Wspierają one rozwój innowacyjności i konkurencyjności regionu. Strategic Policy Intelligence Tools powinny charakteryzować się podejściem integracyjnym, które można rozpatrywać na dwa sposoby. Pierwszy polega na łączeniu możliwych do wykorzystania metod i technik o odmiennych zasadach, ale wzajemnie się uzupełniających i tworzących logicznie uporządkowaną całość. Uzyskany efekt synergii w kombinacji metod jest większy niż suma wyników każdej z nich osobno. W drugim sposobie wykorzystuje się współpracę interesariuszy z różnych środowisk w układzie nauka - administracja publiczna - biznes - społeczeństwo [Kuosa, 2014: 30]. Autorka proponuje traktować Strategic Policy Intelligence Tools jako zestaw technik badawczych tworzących współpracującą sieć powiązań oraz know-how, stanowiących pomost pomiędzy obecną działalnością a niepewną przyszłością. Rozpowszechnieniu Strategic Policy Intelligence Tools służą europejskie projekty, konferencje i warsztaty. Przykładami takich projektów są: RegStrat, Connect2Ideas, CReATE, ForTransRIS, Strategic Policy Intelligent Tools for Better Science Technology Investment Strategies in Europe's Regions. Strategic Policy Intelligence Tools obejmują: ewaluację (evaluation), szacowanie technologiczne (technology assessment), analizę porównawczą (benchmarking), foresight regionalny (regional foresight) [Gavigan i in., 2001].

Ewaluacja jest badaniem oceniającym jakość i wartość projektu lub obiektu z punktu widzenia przyjętych kryteriów w celu jego usprawnienia i rozwoju [Bingham, Felbinger, 2002: 2]. Na szeroką skalę samorząd terytorialny zaczął korzystać z ewaluacji wraz z uruchomieniem europejskich funduszy strukturalnych i Funduszu Spójności Wspólnoty. Szacowanie technologiczne natomiast jest pomiarem i wartościowaniem technologii [Karczewska i in., 2011: 454-462]. Dużą rolę odgrywa przy określaniu inteligentnych specjalizacji regionów (branże, które zapewniają tworzenie innowacyjnych rozwiązań, podniesienie konkurencyjności i zwiększenie wartości gospodarki) w kontekście kluczowych technologii wspomagających (Key Enabling Technologies). Zadaniem benchmarkingu w zarządzaniu terytorialnym (proces terytorialnej organizacji aktywności w obszarach m.in. edukacji, ochrony środowiska, oświaty [Noworól, 2013]) jest mierzenie i porównywanie zamierzeń i osiągnięć danej jednostki terytorialnej w stosunku do wzorca. Od naśladownictwa różni się tym, że wykrywa czynniki usprawniające analizowany proces, ze wskazaniem podobnych możliwości we własnym obiekcie [Luque-Martinez Munoz, Leiva, 2005: 411-423]. Wyniki takiej analizy służą za podstawę doskonalenia. Benchlearning natomiast polega na uczenia się od liderów i twórczym adaptowaniu najlepszych praktyk (best practices) [Love, Smith, 2003: 147-159]. Foresight regionalny jest kolegialnym procesem zbierania informacji o przyszłości i na tej podstawie budowania średnio- i długoterminowej wizji rozwojowej regionu, umożliwiającej podejmowanie bieżących decyzji i mobilizującej wspólne działania [Nazarko, 2013: 8]. Foresight regionalny w sposób planowy łączy oczekiwania zróżnicowanych podmiotów w regionie dotyczące dróg rozwoju sfery społecznej i ekonomicznej w celu formułowania strategicznych przyszłych wizji [Hajduk, 2016: 59-72]. Krzysztof 
Borodako określa foresight regionalny jako ciągły, odnawialny proces kreowany przez partnerów regionalnych, którzy dzieląc się swoją szeroką wiedzą, działają w sieciach, antycypując zmiany, przed jakimi może stanąć region w średniej lub długiej perspektywie [Borodako, 2009: 13]. Na całościową koncepcję regionalnego foresightu strategicznego składa się: foresight regionalno-technologiczny, foresight metropolitarno-technologiczny i foresight rozwoju przestrzennego regionu [Klasik, Kuźnik, 2013: 203-221]. Regionalne studia prospektywne cechują cztery orientacje badawcze: (I) aksjologiczno-normatywna pozwala na ujawnienie kluczowych interesariuszy regionu; (II) systemowa rozpoznaje zbiór kluczowych zmiennych regionu i jego otoczenia terytorialnego; (III) sytuacyjno-eksploracyjna pozwala na budowanie scenariuszy rozwoju sytuacji w otoczeniu regionu; (IV) kreacyjno-decyzyjna służy formułowaniu rekomendacji do polityki strategicznej regionu [Roberge, 2013: 534-524].

Wymienione Strategic Policy Intelligence Tools dysponują ogromnym zestawem technik. Charakteryzują się one zarówno jakościowym, ilościowym, jak i mieszanym podejściem. Na początku procesu podejmowania decyzji ważne są działania inwentaryzacyjne, takie jak badanie dokumentów, skanowanie otoczenia oraz analiza i krytyka czasopiśmiennictwa. W kolejnych etapach istotną rolę odgrywa perspektywiczne myślenie, obejmujące kształtowanie przyszłych sytuacji z wykorzystaniem foresightu, mapowania. Bogaty katalog technik Strategic Policy Intelligence Tools zawiera tabela 1.

Tabela 1

Wybrane techniki Strategic Policy Intelligence Tools

\begin{tabular}{|c|c|c|c|c|}
\hline & $\begin{array}{c}\text { Zbieranie } \\
\text { informacji }\end{array}$ & $\begin{array}{c}\text { Formowanie } \\
\text { informacji }\end{array}$ & Ocena informacji & $\begin{array}{l}\text { Scenariusze } \\
\text { rozwoju }\end{array}$ \\
\hline 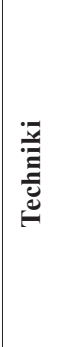 & $\begin{array}{l}\text { Skanowanie } \\
\text { otoczenia } \\
\text { Kolekcjonowa- } \\
\text { nie danych } \\
\text { Obserwacja } \\
\text { Sondaż diagno- } \\
\text { styczny }\end{array}$ & $\begin{array}{l}\text { Analiza SWOT } \\
\text { Analiza STEEPVL } \\
\text { Drzewo istotności } \\
\text { Analiza wpływów } \\
\text { Mapa myśli } \\
\text { Analiza morfologiczna } \\
\text { Analiza wpływów } \\
\text { Analiza multikryterialna }\end{array}$ & $\begin{array}{l}\text { Burza mózgów } \\
\text { Panele ekspertów } \\
\text { Badania ankietowe } \\
\text { Warsztaty przyszłościowe } \\
\text { Grupy fokusowe } \\
\text { Metoda Delphi } \\
\text { Analiza bibliometryczna } \\
\text { Modelowanie statystyczne } \\
\text { Modelowanie ekono- } \\
\text { metryczne }\end{array}$ & $\begin{array}{l}\text { Mapa drogowa } \\
\text { Budowa } \\
\text { scenariuszy } \\
\text { Planowanie pro- } \\
\text { jektowe zorien- } \\
\text { towane na cel }\end{array}$ \\
\hline
\end{tabular}

Źródło: opracowanie własne na podstawie: Clar i in., 2008b; Nazarko, 2013.

Zidentyfikowane techniki Strategic Policy Intelligence Tools można sklasyfikować w ujęciu czasowym. Proces podejmowania decyzji rozpoczyna się od zbierania informacji, potem następuje strukturyzacja istotności informacji, a następnie ich ocena, a kończy się formułowaniem wizji rozwoju (scenariusze rozwoju). Każdy z tych etapów procesu podejmowania perspektywicznej decyzji dysponuje szerokim zestawem technik. 
Zalety stosowania Strategic Policy Intelligence Tools związane są z następującymi ich cechami: partycypacja, oparcie na faktach (evidence-base), mediacja (consensus-building) i wsparcie decyzyjne (decision support). W procesie podejmowania decyzji biorą udział wszystkie zainteresowane strony, które prowadzą rygorystyczną analizę danych empirycznych oraz wzajemnie uczą się budowania konsensusu i realizacji zamierzeń [Clar i in., 2008a: 2].

\section{Zarządzanie rozwojem przestrzennym w ujęciu strategicznym}

Termin zarządzanie rozwojem przestrzennym pojawia się $\mathrm{w}$ wielu strategicznych dokumentach krajowych i regionalnych oraz publikacjach naukowych. Zarządzanie rozwojem przestrzennym obejmuje praktyczne wykorzystanie wiedzy z zakresu ekonomicznej analizy przestrzennej, teorii gospodarki przestrzennej i analizy rynków nieruchomości, prowadzące do umiejętnego wskazania optymalnego użytkowania, sposobów i dróg transformacji funkcji każdego fragmentu przestrzeni wynikających z tych analiz oraz oszacowania kosztów i korzyści, jakich należałoby się spodziewać w wyniku przekształceń funkcji planistycznych. Jest to działanie służące doradzeniu, skąd pozyskać lub jak wygenerować z potencjału ekonomicznego analizowanego obszaru fundusze na przeprowadzenie wspomnianych przekształceń [Bajerowski i in., 2008: 11-12; Fogel, 2012: 21-23]. W literaturze przedmiotu można zauważyć dwie doktryny zarządzania przestrzennego, określane jako strategiczne i planistyczne. Pierwsza ma charakter kreacyjny i jest typowa dla menedżerów, druga natomiast jest podejściem instrumentalnym, którym zajmują się urbaniści i architekci. Autorkę interesuje ujęcie strategiczne zarządzania przestrzennego. Analizując definicje zaproponowane przez teoretyków i praktyków, nasuwa się spostrzeżenie, że zarządzanie rozwojem przestrzennym stanowi ogół czynności organów samorządu terytorialnego i administracji państwowej zmierzających do zaplanowania, zorganizowania, wdrożenia i kontrolowania zagospodarowania przestrzeni [Gaczek, 2003: 15; Mickiewicz, 2015: 199-210]. Artur Hołuj zwraca uwagę, iż zarządzanie rozwojem przestrzennym w obecnych czasach jest procesem szczególnie trudnym, gdyż jest kosztowne, długoterminowe i niezwykle złożone [Hołuj, 2015: 23-33].

Pokrycie planistyczne województw Polski charakteryzuje się dużym zróżnicowaniem: od 5,2\% (kujawsko-pomorskie) do 65,1\% (małopolskie) [Bank Danych Lokalnych GUS, 2016; Śleszyński, 2015]. Ogromnymi problemami są nie ilość, ale jakość planów miejscowych oraz ich konsekwencje finansowe. W szczególności regiony metropolitarne są narażone na nieuporządkowany i niekontrolowany proces rozlewania zabudowy. Analizy prowadzone przez Andrzeja Olbrysza i Jakuba Kozińskiego [2015] pokazały, że w planach miejscowych przeznaczono tereny pod budownictwo mieszkaniowe, które pozwalają na osiedlenie $77 \mathrm{mln}$ osób. W studiach gminnych zaplanowano natomiast jeszcze więcej obszarów 
mieszkaniowych, na których może się osiedlić aż 316 mln osób [Olbrysz, Koziński, 2015: 183-327]. Przy obecnym tempie inwestowania (około 150 tys. mieszkań oddawanych rocznie do użytku, z czego połowę stanowią domy jednorodzinne) daje to rezerwy budowlane na okres 150-210 lat. W wielu gminnych studiach i planach miejscowych przeznaczone pod zabudowę mieszkaniową są takie tereny, których chłonność demograficzna została przekroczona dziesięciokrotnie w stosunku do liczby mieszkańców [Kowalewski i in., 2014: 11-29]. Wiele gmin ponosi lub będzie ponosić ogromne koszty wykupu gruntów pod drogi i koszty budowy infrastruktury technicznej na terenach, które nigdy nie zostaną zabudowane i na terenach zabudowanych ekstensywnie. Według szacunków przedstawionych przez Śleszyńskiego i jego zespół, koszty te wynoszą 40-59 mld zł [Śleszyński i in., 2013: 6]. Taka sytuacja wynika z braku prowadzenia analiz potrzeb rozwojowych gmin i ich sytuacji demograficznej, co jest konsekwencją słabego stosowania Strategic Policy Intelligence Tools w rozwoju przestrzennym i niewykorzystywania ich zalet.

Plan zagospodarowania przestrzennego województwa wskazuje, jakie działania w obszarze kształtowania, użytkowania i przekształcenia przestrzeni są niezbędne do osiągnięcia celów zapisanych w strategii rozwoju województwa. Służy koordynacji w przestrzeni zamierzeń sektorowych, przedsięwzięć o znaczeniu strategicznym oraz stanowi istotną przesłankę dla lokalnych opracowań planistycznych i programowych przygotowywanych przez samorząd województwa. Wyraża pożądany stan do osiągnięcia w określonym przedziale czasowym, strategiczne zarządzanie rozwojem przestrzennym ma natomiast charakter procesowy. Proces ten składa się z czterech zasadniczych etapów: (I) analiza strategiczna; (II) formułowanie planu; (III) implementacja planu; i (IV) sprawdzanie planu [Gawroński, 2010]. Istota procesu strategicznego zarządzania rozwojem przestrzennym została zwizualizowana na rysunku 1.

Zgodnie z przedstawionym schematem strategiczne zarządzanie rozwojem przestrzennym jest procesem ciągłym i powinno się charakteryzować następującymi cechami: identyfikacja priorytetów strategicznych w głównych obszarach interwencji; ocena mocnych i słabych stron regionu w odniesieniu do benchmarków; wyznaczenie mierzalnych celów na poziomie strategicznym, operacyjnym i taktycznym; wprowadzenie mechanizmów controllingu strategicznego. W określonych okresach czasowych na ostatnim etapie następują przegląd i weryfikacja celów strategicznych rozwoju przestrzennego danego terytorium, a także sposobów ich osiągania. Im otoczenie jest bardziej zmienne, tym okresy weryfikacji powinny być krótsze. Wskazania ustawowe sugerują dokonywanie co najmniej raz podczas kadencji organów samorządu terytorialnego przeglądu planu zagospodarowania przestrzennego. Stałym monitoringiem powinny być objęte nie tylko postępy na drodze osiągnięcia celów strategicznych, ale również zmiany zachodzące w otoczeniu, które mogą również determinować konieczność aktualizacji planu. 


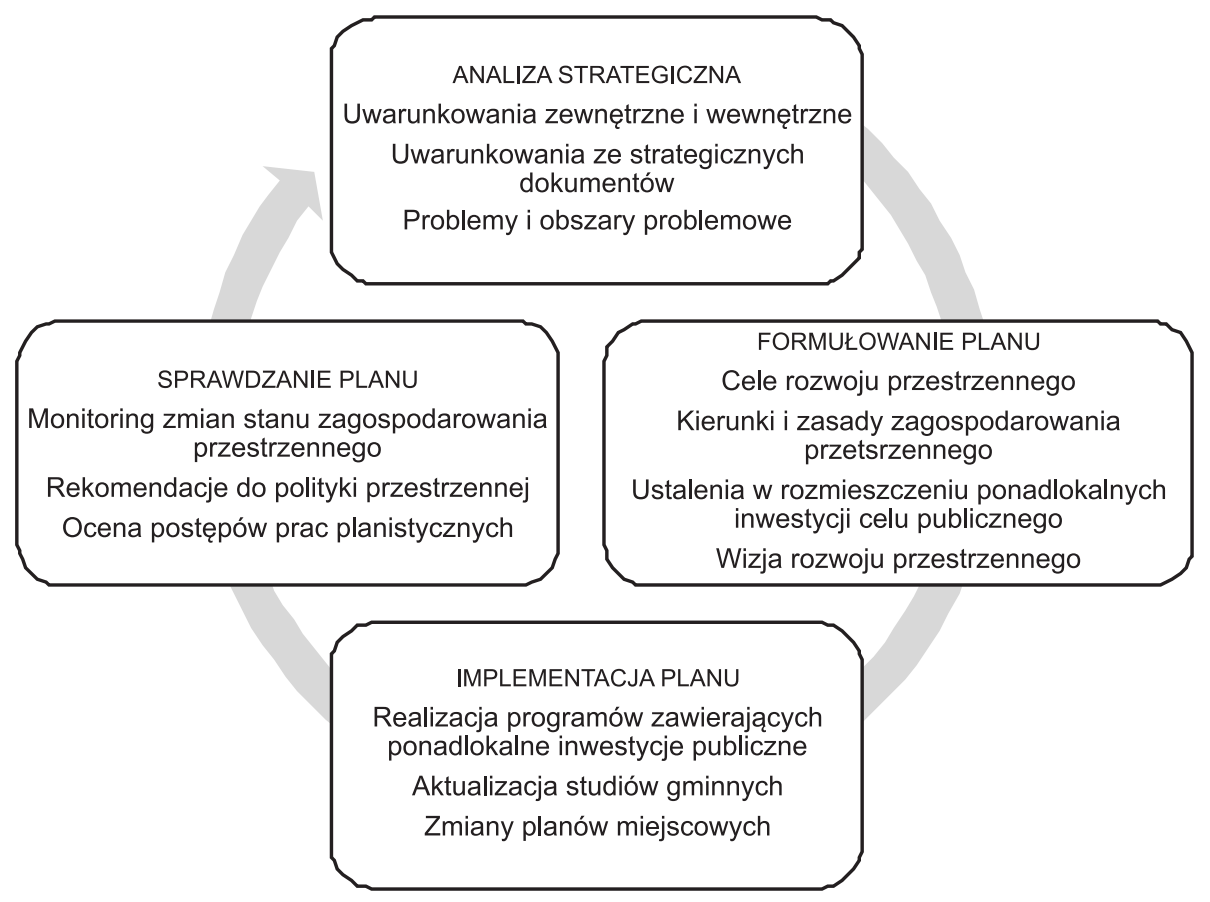

Rysunek 1. Proces strategicznego zarządzania rozwojem przestrzennym

Źródło: opracowanie własne

\section{Strategic Policy Intelligence Tools w zarządzaniu rozwojem przestrzennym}

Strategic Policy Intelligence Tools umożliwiają skuteczne przewidywanie przyszłości rozwoju w perspektywie długookresowej i z powodzeniem powinny być wykorzystywane przez samorząd terytorialny w zarządzaniu rozwojem przestrzennym [CIMA, 2007]. Autorka, w celu określenia celowości ich stosowania, dokonała przeglądu i przeanalizowała plany zagospodarowania przestrzennego województwa pod kątem aktualności i wykorzystanych metod w antycypowaniu rozwoju. Dalsze badania zostały ograniczone do 12 opracowań planistycznych ze względu na dezaktualizację pominiętych (kujawsko-pomorskie, podlaskie, małopolskie, podkarpackie), co zostało wskazane w okresowych ocenach planów zagospodarowania przestrzennego. Najczęściej stosowanymi metodami są: przegląd dokumentów strategicznych i skanowanie otoczenia na etapie określania uwarunkowań wewnętrznych i zewnętrznych regionu. Ze względu na brak informacji w większości planów o przebiegu prac nad dokumentem, można zakładać, że samorządy województw korzystają z dyskusji i konsultacji społecznych. Warto zaznaczyć, że mogą one przybierać również formę spotkań lub warsztatów. 
Rekomendacje i lista wskaźników są wykorzystywane na etapie sprawdzania planu. Informacje o metodach stosowanych przy przygotowywaniu poszczególnych planów zagospodarowania przestrzennego województwa zawiera tabela 2.

Tabela 2

Plany zagospodarowania przestrzennego województw pod względem zastosowanych metod

\begin{tabular}{|c|c|c|c|c|c|c|c|c|c|c|c|c|}
\hline & 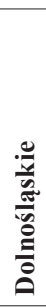 & 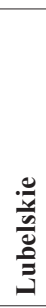 & 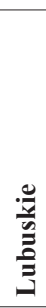 & 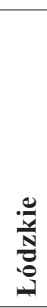 & 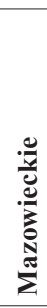 & $\frac{\frac{0}{x}}{\frac{\pi}{0}}$ & $\begin{array}{l}\frac{\mathscr{x}}{0} \\
\frac{0}{0} \\
\vdots \\
0\end{array}$ & 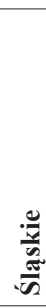 & 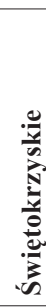 & 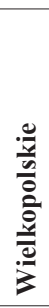 & 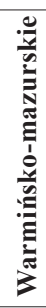 & 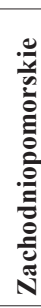 \\
\hline Przegląd dokumentów & + & + & + & + & + & + & + & + & + & + & + & + \\
\hline Dyskusje i konsultacje & & & & & + & + & + & & & & & \\
\hline Skanowanie otoczenia & + & + & + & + & + & + & + & + & + & + & + & + \\
\hline Analiza potrzeb & & & & & & & & & & & + & \\
\hline Analiza porównawcza & & + & + & + & + & + & + & + & + & & + & + \\
\hline Analiza SWOT & & + & + & & & + & + & & + & & & + \\
\hline Analiza PEST & + & & & & & & & & & & & \\
\hline Metoda scenariusza & + & & + & + & & & & + & & & & \\
\hline Prognoza demograficzna & + & + & + & & & & + & & + & & + & + \\
\hline Drzewo celów & + & + & & + & + & + & + & + & + & + & + & \\
\hline Rekomendacje & + & + & + & + & + & + & + & + & + & + & & + \\
\hline Lista wskaźników & & & & + & + & + & + & + & + & + & & + \\
\hline
\end{tabular}

+- metoda stosowana w planie zagospodarowania przestrzennego województwa

Źródło: opracowanie własne

W planach zagospodarowania przestrzennego niedoceniane są Strategic Policy Intelligence Tools. Istotne jest połączenie podejścia ilościowo-jakościowego poprzez kombinację kilku miękkich metod badawczych z twardymi. Rzadko w pracach nad opracowaniami planistycznymi wykorzystywane są metody jakościowe. Macierz SWOT powinna wyprzedzać warsztaty eksperckie (spotkania m.in. z konserwatorem zabytków, zarządcą dróg publicznych, dyrektorem lasów państwowych). Skanowanie uwarunkowań wewnętrznych i zewnętrznych rozwoju przestrzennego jest szczególnie użyteczne przy przygotowaniu listy czynników STEEPVL. Identyfikację głównych aspektów rozwoju przestrzennego, wynikających z kierunków zagospodarowania przestrzennego, należy brać pod uwagę przy konstrukcji scenariuszy w postaci wizji rozwoju przestrzennego. Krzyżową analizę wpływów, wymagającą opinii o warunkowym prawdopodobieństwie, 
należy poprzedzić sondażami i wywiadami z interesariuszami. Metoda priorytetyzacji na etapie określania kierunków rozwoju zagospodarowania przestrzennego pozwoli wyznaczyć priorytetowe zadania dla regionu pod względem ważności i niepewności [Magruk, 2012: 37-46]. Propozycję implementacji Strategic Policy Intelligence Tools na poszczególnych etapach przygotowywania opracowań planistycznych przedstawiono w tabeli 3 .

Tabela 3

Strategic Policy Intelligence Tools w rozwoju przestrzennym

\begin{tabular}{|c|c|c|c|c|}
\hline & $\begin{array}{c}\text { Uwarunkowania } \\
\text { rozwoju } \\
\text { zagospodarowa- } \\
\text { nia przestrzen- } \\
\text { nego }\end{array}$ & $\begin{array}{c}\text { Potencjały i bariery } \\
\text { rozwoju zagospodarowania } \\
\text { przestrzennego }\end{array}$ & $\begin{array}{l}\text { Wizja z kierunkami } \\
\text { rozwoju zagospoda- } \\
\text { rowania przestrzen- } \\
\text { nego }\end{array}$ & $\begin{array}{c}\text { Monitoring } \\
\text { rozwoju } \\
\text { zagospodarowa- } \\
\text { nia przestrzen- } \\
\text { nego }\end{array}$ \\
\hline 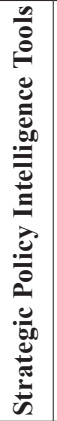 & $\begin{array}{l}\text { Przegląd doku- } \\
\text { mentów strate- } \\
\text { gicznych } \\
\text { Analiza instytu- } \\
\text { cjonalna } \\
\text { Wywiady } \\
\text { Spotkania } \\
\text { Warsztaty } \\
\text { Ankiety }\end{array}$ & $\begin{array}{l}\text { Analiza działań } \\
\text { Analiza SWOT } \\
\text { Analiza PEST } \\
\text { Analiza STEEPVL } \\
\text { Drzewo odniesień } \\
\text { Metoda delficka } \\
\text { Analiza strukturalna } \\
\text { Panele eksperckie } \\
\text { Analiza gry aktorów } \\
\text { Sytuacyjna analiza strate- } \\
\text { giczna }\end{array}$ & $\begin{array}{l}\text { Identyfikacja głów- } \\
\text { nych aspektów } \\
\text { Priorytetyzacja } \\
\text { Scenariusze } \\
\text { Koło przyszłości } \\
\text { Ocena wpływu na } \\
\text { społeczeństwo } \\
\text { Metody kreatyw- } \\
\text { ności } \\
\text { Mapa drogowa }\end{array}$ & $\begin{array}{l}\text { Wskaźniki staty- } \\
\text { styczne } \\
\text { Analiza } \\
\text { wpływów } \\
\text { krytycznych }\end{array}$ \\
\hline
\end{tabular}

Źródło: opracowanie własne

\section{Zakończenie}

Obecnie ogromne znaczenie ma starannie przemyślana i zaplanowana przyszłość rozwoju danego terytorium. Wdrożenie Strategic Policy Intelligence Tools pozwoli budować wspólną wizję rozwoju przestrzennego regionu i, poprzez integrację lokalnych liderów, wzmocni poczucie odpowiedzialności. Artykuł stanowi swego rodzaju studium rozpoznawcze w zakresie możliwości wykorzystania Strategic Policy Intelligence Tools do procesu planowania przestrzennego realizowanego przez polskie regiony. Strategic Policy Intelligence Tools w ujęciu integracyjnym powinny charakteryzować się scalaniem różnych metod identyfikacji szans rozwoju danego terytorium i koordynacją potencjału ze scenariuszami rozwoju terytorium oraz połączeniem różnorodnych potrzeb interesariuszy. Autorka zaproponowała zaimplantowanie Strategic Policy Intelligence Tools do analizy rozwoju przestrzennego. Niestety są one słabo wykorzystywane, co potwierdził przeprowadzony przegląd planów zagospodarowania przestrzennego województwa. Wynika to przede wszystkim z braku klarownych i wyrazistych 
wytycznych w literaturze krajowej, co ogranicza wspomniane pełne i skuteczne wykorzystanie Strategic Policy Intelligence Tools. Brak polskojęzycznego odpowiednika terminu Strategic Policy Intelligence Tools powoduje trudności w stosowaniu tego narzędzia. Wykorzystanie Strategic Policy Intelligence Tools przy opracowywaniu planu zagospodarowania przestrzennego województwa może zatem w konsekwencji sprzyjać dynamizacji procesów rozwojowych w regionie.

Zastosowanie Strategic Policy Intelligence Tools ułatwi decydentom podejmowanie bezstronnej, właściwej i perspektywicznej decyzji oraz określanie kierunków rozwoju przestrzennego w długoletniej perspektywie czasowej. Pozwoli właściwie powiązać zagadnienia rozwoju społeczno-gospodarczego z przestrzennym rozwojem w regionie. Umożliwi zidentyfikowanie istotnych problemów zagospodarowania przestrzennego pojawiających się w ogromnej skali wzdłuż korytarzy transportowych, na obszarach przyrodniczo cennych i terenach zurbanizowanych. Przyczyni się do ograniczenia ponoszonych przez samorządy terytorialne olbrzymich konsekwencji finansowych przeznaczania terenów pod zabudowę mieszkaniową i związanych z budową infrastruktury. Ułatwi prowadzenie analiz potrzeb i możliwości rozwoju danego terytorium.

Autorka planuje przygotować metodykę analizy rozwoju przestrzennego z wykorzystaniem Strategic Policy Intelligence Tools.

\section{Bibliografia}

Bank Danych Lokalnych GUS, http://stat.gov.pl [dostęp: 12.10.2016].

Bajerowski T. (red.) (2008), Zarządzanie przestrzenne. Teoretyczne i praktyczne aspekty prognozowania finansowych skutków opracowań planistycznych, Wydawnictwo Uniwersytetu Warmińsko-Mazurskiego, Olsztyn.

Bingham R.D., Felbinger C.L. (2002), Evaluation in Practice: A Methodological Approach, Seven Bridges Press, New York-London.

Borodako K. (2009), Foresight w zarzadzaniu strategicznym, C.H. Beck, Warszawa.

CIMA (2007), Chartered Institute of Management Accountants, Strategic Analysis Tools, Topic Gateway, Series No. 34, http://www.cimaglobal.com/Documents/ImportedDocuments/cid_tg_strategic_analysis_tools_nov07.pdf.pdf [dostęp: 15.10.2016].

Clar G., Acheson H., Hafner-Zimmermann S., Sautter B., Buczek M., Allan J. (2008a), Strategic Policy Intelligence Tools - A Guide. Enabling better RDTI policy-making in Europe's Regions, https://www.ibs.ee/wp-content/uploads/Regstrat_Guide_Final.pdf [dostęp: 15.10.2016].

Clar G., Sautter B., Hafner-Zimmermann S. (2008b), Strategic Cluster Development: Applying Strategic Policy Intelligence to Create a Joint Research Agenda, http://www.intelspace.eu/wp-content/uploads/2012/07/Clar-Sautter-and-Hafner-Zimmermann-2008-Strategic-Cluster-Development.pdf [dostęp: 17.10.2016].

Clar G., Acheson H., Hafner-Zimmermann S., Sautter B. (2008c), FTA Approaches Integrated in the broader Strategic Policy Intelligence (SPI) Context - Improving Policies, Strategies and RTDI-Investments in Europe's Regions, III International Seville Seminar on Future-Oriented Technology Analysis: Impacts and Implications for Policy and Decision-Making. 
Fogel P. (2012), Wskaźniki oceny polityki i gospodarki przestrzennej w gminach, Biuletyn KPZK PAN, 250.

Gavigan J. i in. (2001), Country Guides Regional Foresight, Foresight for Regional Development Network, http://foresight.jrc.ec.europa.eu/documents/eur20128en.pdf [dostęp: 19.10.2016].

Gaczek W.M. (2003), Zarządzanie w gospodarce przestrzennej, Oficyna Wydawnicza Branta, Poznań.

Gawroński H. (2010), Zarządzanie strategiczne w samorzadzach lokalnych, Wolters Kluwer Polska, Warszawa.

Hajduk S. (2016), Foresight regionalny jako instrument perspektywicznego rozwoju przestrzennego, „Przedsiębiorczość i Zarządzanie”, 17(9).

Halicka K. (2015), Prospektywna analiza technologii [w:] R. Knosala (red.), Innowacje w zarzadzaniu i inżynierii produkcji, t. 2, Oficyna Wydawnicza Polskiego Towarzystwa Zarządzania Produkcją, Opole.

Hołuj A. (2015), Wybrane aspekty zarządzania rozwojem na obszarach dotkniętych procesem urban sprawl $w$ Polsce, „Zarządzanie Publiczne”, 1(29).

Karczewska M., Materzok J., Skonieczny J. (2011), Współczesne narzędzia oceny technologii [w:] Knosala R. (red.), Innowacje w zarządzaniu i inżynierii produkcji, Polskie Towarzystwo Zarządzania Produkcją, Opole.

Klasik A., Kuźnik F. (2013), Studia foresightowe jako podstawa polityki strategicznej [w:] W.M. Gaczek (red.), Dynamika, cele i polityka zintegrowanego rozwoju regionów. Aspekty teoretyczne i zarzadzanie w przestrzeni, Bogucki Wydawnictwo Naukowe, Poznań.

Kowalewski A. i in.. (2014), Raport o ekonomicznych stratach $i$ społecznych kosztach niekontrolowanej urbanizacji, Fundacja Rozwoju Demokracji Lokalnej, Warszawa, http://www. kongresbudownictwa.pl [dostęp: 20.10.2016].

Kuosa T. (2014), Towards Strategic Intelligence - Foresight, Intelligence, and Policy-Making, „Dynamic Futures Publications” No. 1, https://www.fhs.se/documents/Externwebben/ forskning/centrumbildningar/CATS/publikationer/Towards\%20Strategic\%20Intelligence.pdf [dostęp: 12.10.2016].

Love P., Smith J. (2003), Benchmarking, Benchaction and Benchlearning: Rework Mitigation in Projects, „Journal of Management in Engineering”, 19(4), s. 147-159.

Luque-Martinez Munoz T., Leiva F. (2005), City Benchmarking: A Methodological Proposal Referring Specifically to Granada, „Cities”, 22(6).

Magruk A. (2012), Struktury hybrydowe w studiach przyszłości, „Economics and Management", 4.

Mickiewicz P. (2015), Zarzadzanie przestrzenia w zarządzaniu publicznym, „Marketing i Rynek", 10.

Nazarko J. (2013), Regionalny foresight gospodarczy. Metodologia i instrumentarium badawcze, ZPWiM, Warszawa.

Noworól A. (2013), Ku nowemu paradygmatowi planowania terytorialnego, CeDeWu, Warszawa.

Olbrysz A., Koziński J. (2015), Raport o finansowych efektach polskiego systemu gospodarowania przestrzenia [w:] P. Kopyciński (red.), Sprawne państwo. Badania nad kierunkami zmian $w$ funkcjonowaniu samorzadu terytorialnego w Polsce, Małopolska Szkoła Administracji Publicznej, Kraków, http://www.pri.msap.pl/doki/publ/SWPZ_Systemowe_zmiany_2015.pdf [dostęp: 12.10.2016]. 
Roberge I. (2013), Futures Construction in Public Management, „International Journal of Public Sector Management", 26(7).

Skonieczny J. (2006), Narzędzia SPI w zarządzaniu regionami europejskimi, Politechnika Wrocławska, Wrocław, http://www.dcsr.wroc.pl/files/File/konferencja20060629/prez/14 narzedzia_spi.pdf [dostęp: 13.10.2016].

Śleszyński P. (red.) (2015), Analiza stanu i uwarunkowań prac planistycznych w gminach na koniec 2013 roku, Instytut Geografii i Przestrzennego Zagospodarowania PAN, Warszawa, https://www.mr.gov.pl/media/5139/analiza_2013.pdf [dostęp: 11.10.2016].

Śleszyński P., Górczyńska M., Zielińska B. (2013), Szacunek prognozowanych i zrealizowanych wptywów $i$ wydatków w Polsce wynikających z uchwalenia miejscowych planów zagospodarowania przestrzennego, Instytut Geografii i Przestrzennego Zagospodarowania PAN, Warszawa.

Tübke A., Ducatel K., Gawigan J., Moncada-Paternò-Castello P. (2001), Strategic Policy Intelligence: Current Trends, the State of Play and Perspectives - S\&T Intelligence for Policy-Making Processes, http://ftp.jrc.es/EURdoc/eur20137en.pdf [dostęp: 15.10.2016]. 